\title{
TOWARDS A NEW UNDERSTADING OF THE CURSE OF EVE: FEMALE SEXUAL PAIN IN GENESIS 3:16 AND OTHER ANCIENT TEXTS ${ }^{1}$
}

\author{
Renate Marian van Dijk-Coombes \\ Research Focus Area Ancient Texts: Text, Context and Reception \\ Faculty of Theology \\ North-West University
}

\begin{abstract}
Painful sexual intercourse is the lived experience of many women, but little research has been done on the condition, and it is seldom discussed, either in private conversations or in the media. This appears to also have been true in ancient society, where few texts mention pain associated with sexual intercourse. Three ancient sources may reference or address the condition, these being Ramesseum Medical Papyrus IV, dating from the $13^{\text {th }}$ Dynasty of Egypt during the $18^{\text {th }}$ century BCE, Enki and Ninhursaga, a Sumerian mythical narrative, and Gen 3:16, the so-called Curse of Eve. This article will examine these three sources, analysing the translations of specific words and how these affect the understanding of the relevant passages. The paper will further investigate specifically the message which Gen 3:16 gives to women suffering from painful sexual intercourse, and how religious orthodoxy and a strict upbringing can be both a factor in the development of painful sexual intercourse, as well as an inhibiting factor in the treatment thereof.
\end{abstract}

Keywords: Sexual pain; Genesis 3:16; Ramesseum Medical Papyrus IV; Enki and Ninhursaga; Hermeneutics

\section{Introduction}

The fourth edition of The diagnostic and statistical manual of mental disorders (DSMIV-TR), published in 2000, describes two sexual pain disorders, dyspareunia and vaginismus. Dyspareunia is defined as:

(A) Recurrent or persistent genital pain associated with sexual intercourse in either a male or a female; (B) The disturbance causes marked distress or interpersonal difficulty; (C) The disturbance is not caused exclusively by Vaginismus or lack of lubrication, is not better accounted for by another Axis I disorder (except another Sexual Dysfunction), and is not due exclusively to the direct physiological effects of

\footnotetext{
The idea for this paper originated from a series of lectures by Christo van der Merwe on the complexities of translating Genesis 1-3 at Stellenbosch University in 2018. The paper was first presented at the conference Sexual reformation? Theological and ethical reflection on human sexuality, held at the Faculty of Theology, Stellenbosch University, on 6-7 May 2019. My thanks to the organisers of and participants in this conference and to the anonymous reviewers of Scriptura for their comments. My thanks also to Gideon Kotzé for his comments and suggestions, in particular on some technical points regarding the translation of Genesis 3:16. The translation and argument are my own, and any faults or errors lie with me.
} 
a substance (e.g., a drug of abuse, a medication) or a general medical condition. (American Psychiatric Association 2000:556)

Vaginismus, on the other hand, is defined as:

(A) Recurrent or persistent involuntary spasm of the musculature of the outer third of the vagina that interferes with sexual intercourse; (B) The disturbance causes marked distress or interpersonal difficulty; (C) The disturbance is not better accounted for by another Axis I disorder (e.g., Somotization Disorder) and is not due exclusively to the direct physiological effects of a general medical condition. (American Psychiatric Association 2000:558)

Engman (2007:2 et passim) differentiates between two forms of vaginismus: total vaginismus, in which penetration is impossible, and partial vaginismus, in which penetration is possible, but painful. Partial vaginismus appears to be more common, but is more difficult to diagnose, and is perhaps, for this reason, more pernicious.

Due to the highly comorbid nature of these two disorders, as well as the difficulty in distinguishing between them, in the fifth edition of The diagnostic and statistical manual of mental disorders (DSM-5), published in 2013, they were merged to represent genitopelvic pain/penetration disorder (GPPPD), a condition which can only affect women. GPPPD is defined as:

(A) Persistent or recurrent difficulties with one (or more) of the following: 1. Vaginal penetration during intercourse; 2 . Marked vulvovaginal or pelvic pain during vaginal intercourse or penetration attempts; 3. Marked fear or anxiety about vulvovaginal or pelvic pain in anticipation of, during, or as a result of vaginal penetration; 4 . Marked tensing or tightening of the pelvic floor muscles during attempted vaginal penetration; (B) The symptoms in Criterion A have persisted for a minimum duration of approximately 6 months; (C) The symptoms in Criterion A cause clinically significant distress in the individual; (D) The sexual dysfunction is not better explained by a nonsexual disorder or as a consequence of a severe relationship distress (e.g. partner violence) or other significant stressors and is not attributable to the effects of a substance/medication or another medical condition. (American Psychiatric Association 2013:437) ${ }^{2}$

Whatever the medical term or terms used to define painful sexual intercourse, it is the lived experience of many women. While the exact prevalence is unknown, according to the DSM-5, it affects as much as $15 \%$ of American women (American Psychiatric Association 2013:438). ${ }^{3}$ To put this in perspective, only $1 \%$ of the population suffers

2 Medical (specifically gynaecological) literature may still differentiate between dyspareunia and vaginismus (e.g. Mizrahi 2018:13). Vaginismus may also be viewed as a type or cause of dyspareunia (e.g. Smith, Pukall and Boyer 2009:208), along with other types or causes such as vulvodynia, pain in the vulva, and its subtype vulvar vestibulitis or provoked vestibulodynia, in which the pain is localised to the vulvar vestibule area (LoFrisco 2011:573).

3 It must be noted though, as Bergeron, Corsini-Munt, Aerts, Rancourt and Rosen (2015:159) point out, that "these conditions are still poorly understood, with only $60 \%$ of afflicted women seeking treatment and $52 \%$ of those never receiving a formal diagnosis". As reported by Hayes, Bennett, Dennerstein, Taffe and Fairley (2008:499), there is a lot of variation in prevalence in various studies, with estimates as low as $0,4 \%$ and as 
from autism; $5 \%$ of children and 2, 5\% of adults suffer from ADHD; $7 \%$ of the population suffer from major depressive disorder; $7 \%$ suffer from social anxiety disorder, and 1,2\% suffer from obsessive-compulsive disorder (American Psychiatric Association 2013:55, 61, 165, 204, 239), all of which are much more widely known than the sexual pain disorder(s). An even better comparison is to compare female sexual pain disorders to male sexual dysfunctions - less than $1 \%$ of men suffer from delayed ejaculation (American Psychiatric Association 2013:425); only 1-3\% of men are diagnosed with premature or early ejaculation (American Psychiatric Association 2013:444); and "approximately $2 \%$ of men younger than age 40-50 years complain of frequent problems with erections" (American Psychiatric Association 2013:427), or with erectile disorder (although this number obviously increases for men older than 60-70 years). In other words, the three main male sexual dysfunctions affect about $4-6 \%$ of men - less than half the total of women affected by chronic sexual pain.

For such a common disorder, little research has been done on female sexual pain, and it is seldom discussed, either in private conversations or in the media. ${ }^{4}$ Medical literature, when it mentions the history of female sexual pain, or the history of the study of female sexual pain, references the first description of painful sexual intercourse as being presented in the Ramesseum Medical Papyrus $I V .{ }^{5}$

\section{Egyptian Ramesseum Medical Papyrus IV}

The Egyptian Ramesseum Medical Papyri are a collection of papyri from a late $13^{\text {th }}$ Dynasty tomb under the Ramesseum, the mortuary temple of Ramses II (the Great) of the $19^{\text {th }}$ Dynasty. They are dated around the end of the $18^{\text {th }}$ century BCE, written in hieratic, and, as the name suggests, deal with medical matters (Nunn 2002:39). Ramesseum Medical Papyrus IV deals with gynaecological issues related to pregnancy (including contraception), birth and the protection of the new-born.

According to Costa Talens and Colorado Vicente (1971:275), Columns 3 and 4 of Fragment A of Ramesseum Medical Papyrus IV reads, "(Una mujer que) tiene dolor en su kn s, tiene dolor en su coito (= durante su coito) y cosas no retenidas ... (si examinas) su porción inferior del abdomen (= hipogastrio) y lo encuentras..." Barns (1956:25) suggests that the final section of Column 3 "may refer to a discharge which will not stop", and Binik, Meana, Berkley and Shalife (1999:211) believe that this links painful

high as $61 \%$. This variation may be due to the study design of the studies conducted. The prevalence of GPPPD quoted in the DSM-5 has been used, along with the prevalence of other disorders, as the study design for these is the same, and therefore provides consistency in comparisons.

4 Although vaginismus has recently been portrayed in two Netflix television series, the British comedy-drama Sex education (2019-), particularly in the final episode of its second season (2020), and the German-

American drama miniseries Unorthodox (2020).

$5 \quad$ See for example Binik, Meana, Berkley and Shalife (1999:211) and Amalraj, Kelly and Bachmann (2009:1). Medical literature further references the first record of vaginismus as appearing in Trotula of Salerno's The diseases of women, as for example Binik, Meana, Berkley and Shalife (1999:211) and Engman (2007:1). However, Trotula provides recipes for a "constrictive for the vagina so that they may appear as if they were virgins" (De curis mulierum §190-195, transliteration and English translation in Green 2001:144-147) for the purpose of producing fake bleeding in order for a woman to deceive a man into believing she is a virgin, and perhaps also for enhancing friction for vaginal intercourse (Green 2001:42), and thereby as a means to increase male sexual pleasure. This does not refer to female sexual pain.

6 "(A woman who) has pain in her $\mathrm{k} \mathrm{n} \mathrm{s}$, has pain in her coition (=during her sexual intercourse) and things do not stop [descending from it] ... (if you examine) her lower abdomen (= hypogastrium) and you find ..." 
sexual intercourse with abnormal menstruation. This fits well with what is known medically - there are various gynaecological conditions such as uterine fibroids and endometriosis which can cause abnormal periods and can also cause pain during sex. ${ }^{7}$

The meaning of " $\mathrm{k} \mathrm{n} \mathrm{s"} \mathrm{is} \mathrm{uncertain,} \mathrm{but} \mathrm{it} \mathrm{almost} \mathrm{certainly} \mathrm{refers} \mathrm{to} \mathrm{the} \mathrm{vulva} \mathrm{or}$ vagina (Costa Talens and Colorado Vicente 1971), ${ }^{8}$ and the text therefore describes a woman who experiences pain in her reproductive organs. Whatever the translation of " $\mathrm{k}$ $\mathrm{n}$ s", the text also refers to a woman who "has pain in her coition (=during her sexual intercourse)", and therefore clearly describes female sexual pain. ${ }^{9}$

Being a medical text, Ramesseum Medical Papyrus IV describes the conditions experienced by a woman, and presumably the missing piece of Fragment A of Ramesseum Medical Papyrus IV would have suggested some sort of treatment. The text is clean and concise, almost "sterile", and offers no insight into either the lived experience of women suffering in this manner, or how such a condition may have been viewed. This is not the case with our other ancient texts.

\section{Enki and Ninhursaĝa}

The second text to be examined which mentions female sexual pain is Enki and Ninhursaga. ${ }^{10}$ This is a Sumerian mythical narrative which survives from the Old Babylonian Period (ca. 1830-1531 BCE). To summarise the points which are important to this discussion, the narrative recounts how Enki marries Ninhursaga, and then has a series of incestuous relations with his succeeding daughters, Ninnisig, Ninkura and Uttu. When Uttu reaches maturity, Ninhursaga advises her not to sleep with Enki, and the two (Enki and Uttu) marry. The sexual encounter between Uttu and Enki after they are married, is narrated in lines 178-187,

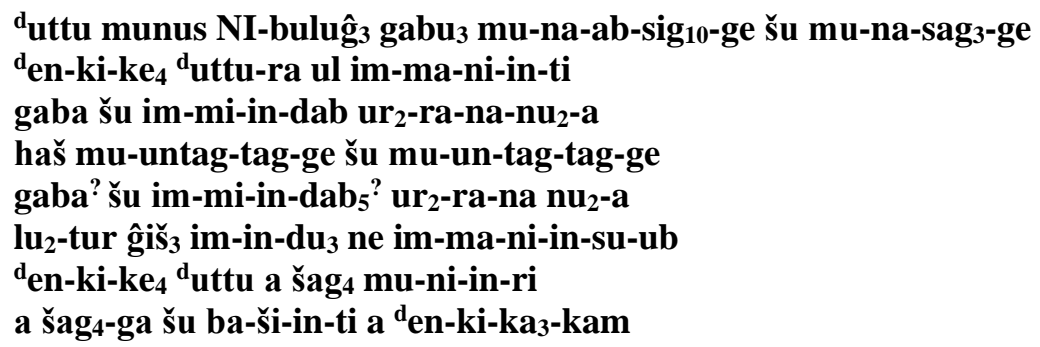

For more on uterine fibroids and female sexual pain, see Zolnoun and Shaw (2009), and for more on endometriosis and female sexual pain, see Droz and Howard (2009).

$8 \quad$ For example, Gardiner (2001:597) translates k n s as "pubic region", while Faulkner (1991:286) translates it tentatively as "pubic region (?)". Erman and Grapow (1982:134) translate it rather broadly "als Körperteil des Menschen zwischen After und Geschlechtsteilen" (as human body part between anus and genitals).

9 The Kahun Medical Papyrus also discusses vaginal/vulvar pain twice, once in paragraph 3, which prescribes the consumption of oil or fat as treatment for a woman with pain in her lower body (including $\mathrm{k} \mathrm{n} \mathrm{s),} \mathrm{and} \mathrm{in}$ paragraph 9 , which prescribes the drinking of a potion for a woman with pain in her $\mathrm{k} \mathrm{n} \mathrm{s}$ and other parts of her body (Westendorf 1999:9). In neither of these cases is the pain explicitly associated with sexual intercourse, and for this reason they are not discussed in this article.

10 For a complete treatment of this text in French, see Attinger (1984), and for a German treatment see Römer (1993:363-386). For an English translation, see Jacobsen (1987:181-204). See also ETCSL (Electronic Text Corpus of Sumerian Literature) 1.1.1., with ETCSL c.1.1.1 at http://etcsl.orinst.ox.ac.uk/cgibin/etcsl.cgi?text=c.1.1.1\# for a transliteration and ETCSL t.1.1.1 at http://etcsl.orinst.ox.ac.uk/cgibin/etcsl.cgi?text=t.1.1.1j\# for an English translation. 


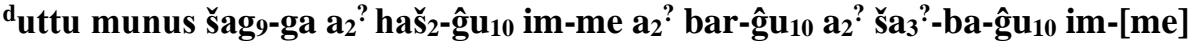
dnin-hur-saĝ-ĝa $a_{2}$ a hašn-ta ba-an-tag-tag

Uttu, the exalted (?) woman, ... to the left for him, waved the hands for him. Enki aroused Uttu. He clasped her to the bosom, lying in her crotch, fondled her thighs, fondled her with the hand. He clasped her to the bosom, lying in her crotch, made love to the youngster and kissed her. Enki poured semen into Uttu's womb and she conceived the semen in the womb, the semen of Enki.

Uttu, the beautiful woman, cried out: "Woe, my thighs." She cried out: "Woe, my body. Woe, my heart." Ninhursaĝa removed the semen from the thighs.

(ETCSL 1.1.1 lines 178-187)

Line 186, which is the important line in terms of female sexual pain, has been translated in various ways. For example, Kramer and Maier, in their book Myths of Enki, the Crafty God translate it as follows (1989:28):

Uttu the seductive women says: "Oh, the power [in my] body!" says: "Oh, the power inside!

Oh, my power on the outside!"

This translation has several problems, including $\mathbf{a}_{2}$ being translated twice, as both "oh" and "power". ${ }^{11}$ In this context, $\mathbf{a}_{2}$ may better be translated as a soothing expression or interjection of pain, ${ }^{12}$ and Dicksen (2007:18) translates line 186 as

"Ah! my thighs! Ah! my body! Ah! my belly/womb!"

Dicksen's translation, as well as that in the ETCSL, render $\mathbf{a}_{2}$ as a soothing expression or expression of pain, "ah!" or "woe" more accurately. ${ }^{13}$ Indeed, Edzard (2003:167) translates it as "woe" or "ouch". ${ }^{14}$ This expression indicates that Uttu is in pain, and she calls out the areas which are in pain - her thighs, her body and her womb. Uttu's reaction to her sexual encounter is vastly different to those of Enki's previous sexual partners. As Frymer-Kensky (1992:22) states, they "had all been instantly responsive to Enki's sexual overtures. They had sex readily, conceived easily, underwent pregnancies which lasted nine days rather then (sic) nine months, and then gave birth effortlessly ... By contrast, Uttu, who was not instantly available, has difficulty in pregnancy." It may be, however, that the pain is not a consequence of pregnancy or childbirth, but of sexual intercourse

11 ePSD (Electronic Pennsylvania Sumerian Dictionary): $\mathbf{a}_{2}:$ 8. power. Akkadian: ahu; idu.

12 The phonogram a may also be translated as "semen" (ePSD: a: "water; semen; progeny"), but in Enki and Ninhursaga is differentiated from the interjection or exclamation by the use of different cuneiform signs, a for semen, and $\mathbf{a}_{2}$ for the soothing expression. See also Rodin (2014:152) for more on $\mathbf{a}_{2}$ as a phonetic variant of a, and as marking pain or discomfort.

13 See also Attinger's (1984:23) translation, "Hélas, mes cuisses, hélas, mon corps, hélas, mon ventre!" (Alas, my thighs, alas, my body, alas my belly!).

14 See also Krecher (1966:149) who translates u8-a a-a as "in Weh und Ach" (in woe and oh). 
itself. $^{15}$ Dickson (2007:3) suggests this when he states, "Uttu experiences pain, presumably during intercourse itself or else, possibly, in the act of childbirth", although this is not explored further.

It is of course possible that Uttu is in pain because she is pregnant. That women in Mesopotamia experienced painful pregnancies is expressed in Sumerian Proverbs, for example UET 6/2, 303 from Ur, "Illness is 'good' (i.e. better) / Pregnancy is painful / Pregnancy and sickness (i.e. morning sickness) ... is much (worse)" (Peterson 2019:588). ${ }^{16}$ Ninhursaga removing Enki's semen from Uttu's womb may also support the understanding that Uttu is experiencing a painful pregnancy. However, Uttu experiences pain straight away, and this is far too early in pregnancy, if there is any pregnancy, for Uttu to be experiencing a painful pregnancy. Moreover, Enki's semen is removed - only his semen, not a foetus or a baby - suggesting that fertilisation, or conception, has not taken place. Indeed, Leick (1994:50) states that it is an exception that conception has not taken place with Uttu. This all suggests that it is not pregnancy, but the act of sexual intercourse itself which causes Uttu's pain.

Dicksen's (2007:18) translation of šag/šag 4 as "belly/womb" instead of "heart", which is the more traditional meaning and translation of the word, ${ }^{17}$ makes sense considering that this is the location in Uttu's body into which Enki "pours his semen". However, the progression of Uttu's experienced pain through her thighs, her body and her heart expresses well the varieties of pain experienced by women suffering from sexual pain disorders as being both physical and mental. In fact, many women struggle more with the mental anguish associated with painful sex than with the actual physical pain. ${ }^{18}$

Uttu's sexual pain is in sharp contrast to the ease of sexual intimacy, pregnancy and childbirth experienced by Enki's previous sexual partners. However, as Frymer-Kensky (1992:23) states, this may "represent a belief, found also in the Bible and some of our own folk beliefs, that cultured, civilized women do not give birth with the same ease as 'natural' women. The domestication of women makes them more 'civilized,' farther removed from animals and nature, and as a result they no longer are able to perform the 'natural' function of childbirth with ease." From what is preserved of the text there does not seem to be any judgement on this: Uttu experiences sexual pain, but this is because she is a "proper" lady, and the courtship likewise has been "proper". This gives the impression that it is "good girls" who experience sexual pain, something which may be borne out by modern studies. ${ }^{19}$

\footnotetext{
15 Attinger (1984:43) suggests that "Enki a certainement abuse d'Uttu" (Enki certainly abused Uttu). Jacobsen (1987:184) similarly states that Enki takes Uttu "by force". Considering the rest of the sexual encounter, particularly lines 178-179 in which Uttu entices Enki to join her and is aroused by him, this seems unlikely.

16 Translated in the ETCSL 6.2.3 as "To be sick is alright, to be pregnant is painful; to be pregnant and sick is just too much" and translated by Alster (1997:39) as "To be sick is (relatively) 'good,' to be pregnant is bad, to be pregnant and sick is too much." See also Attinger (2019:162) for more on various translations of this proverb. For the English translation see ETCSL t.6.2.3 at http://etcsl.orinst.ox.ac.uk/cgibin/etcsl.cgi?text=t.6.2.3\#, and for a transliteration see ETCSL c.6.2.3 at http://etcsl.orinst.ox.ac.uk/cgibin/etcsl.cgi?text=c.6.2.3\#.

17 ePSD (Electronic Pennsylvania Sumerian Dictionary): šag: 1. "inner body, 2. heart, 3. in, inside”. Akkadian: libbu. The Sumerian for "womb" is šagtur, ePSD: šagtur: 1. "womb”. Akkadian: šašūru.

18 See for example Shallcross, Dickson, Nunns, Mackenzie and Kiemle (2018) for the psychological effects of vulvodynia on women, and Ward and Ogden (1994) for the psychological effects of vaginismus.

19 Discussed in greater detail below.
} 


\section{Genesis 3:16 - The Curse of Eve}

The final ancient text to be discussed is the so-called Curse of Eve in Gen 3:16. ${ }^{20}$ This is part of the punishments meted out by God to the serpent, Eve and Adam after Adam and Eve ate from the Tree of Knowledge. God curses Eve as follows,

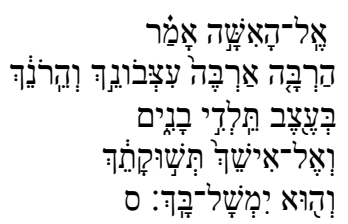

To the woman he (God) said, "I will greatly increase your pain in/and your pregnancy/conception. In pain you will bear children. And your desire will be for your husband, and he will rule over you."

This has been translated in various ways. For example, the ESV translates this verse as,

To the woman he [ie God] said,

"I will surely multiply your pain in childbearing;

in pain you shall bring forth children.

Your desire shall be contrary to your husband,

but he shall rule over you.

While the NRSV translates it as follows,

To the woman he said,

"I will greatly increase your pangs in childbearing;

in pain you shall bring forth children,

yet your desire shall be for your husband,

and he shall rule over you."

With regard to female sexual pain ${ }^{21}$ the first part of the curse needs to be examined and considered. In the above examples, the ESV translates הרבה ארבה as "I will surely multiply", while the NRSV translates it as "I will greatly increase". Both can be accurate renderings of the infinite absolute, but the NRSV translation, "I will greatly increase" may make more sense when the rest of the utterance is taken into consideration. In this regard, both the ESV and the NRSV translate חרון as "childbearing", but this is not the only way the word can be translated. It may also be translated as "pregnancy", as in the Good News Translation, "I will increase your trouble in pregnancy", and as

20 Neither Adam nor Eve are explicitly cursed as the serpent is in Gen 3:14 or the ground is (because of Adam) in Gen 3:17. However, for this paper, the common notion that Eve was cursed is more important than whether or not God's address to her was an actual curse or not. For this reason, as well as for convenience, the term Curse of Eve is used throughout.

21 There are of course other interpretations of this verse. For example, Meyers (1988:105) translates it as "I will greatly increase your toil and pregnancies", while Moss and Baden (2015:87) build on Meyers' interpretation, and argue that "Eve's curse is not that she will experience pain in childbirth. It is that she will be pregnant in the first place". 
"conception". 22 This last translation, "conception", is favoured in the King James Bible, "I will greatly multiply thy sorrow and thy conception", as well as most of the revisions of the King James Bible, the American Standard Version, and English Revised Version, amongst others. According to Smith (2018:106), the translation is literally "your painful labor and your conception", and that "[t]he language is broad enough to include the suffering of pregnancy, childbirth and the whole reproductive process". In this regard, Halladay (1988:84) also offers "sensory pleasure" as a translation of חרון, and Swanson (1997) expands this to, "sensory pleasure, i.e., the pleasures of the sexual act just prior to the pregnancy and gestation and birth". Indeed, as Van Ruiten (2003:4) states, "חרון in Gen 3:16a seems to concern more the beginning of pregnancy than its end", and according to Meyers (1988:102), "the word shows a tendency to be more associated with the initiation of pregnancy rather than with its duration or conclusion". In other words, "conception" here can mean the act of sexual intercourse itself.

There is also disagreement over the translation of עצבון as it can be translated as "toil", "pain/distress", or "sorrow". ${ }^{23}$ But when combined with the understanding of חרון as conception/sexual intercourse, it becomes clear that the "pain" or "sorrow" (and here "pain" is a better fit) is associated with the sexual act. Westermann (1974:356) suggests that עצבון are a hendiadys, an interpretation which is suggested in the NRSV translation, "I will greatly increase your pangs in childbearing". ${ }^{24}$ Taking instead as "conception" or "sexual intercourse", the clause in this way could then read, "I will greatly increase your painful conception (i.e. your painful sexual intercourse)". The Curse of Eve by God may therefore be that sexual intercourse is, or at least can be, painful for women.

\section{Religion and female sexual pain}

This curse was given as punishment to Eve - and by extension to women - and the message is highly problematic. As Gellman (2006:320) states, "The story of Adam and Eve in Genesis, chs. 2-3, has historically been taken to endorse male normativity, especially in sexuality." The Adam and Eve story has been used for millennia to justify and enforce the unequal treatment of women by men - women are inferior to men

22 חרון is a hapax legomenon, a noun recorded only in Gen 3:16 (Fischer 2018:252), and Gertz (2018:142) notes that there were already difficulties in translating it in the LXX, where חרון as Schwangerschaft was translated

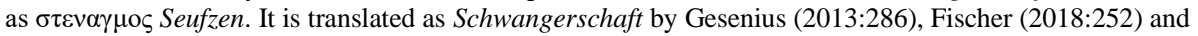
Westermann (1974:356). Brown, Driver and Briggs (2001:248) translate it more broadly as "conception, pregnancy". Koehler and Baumgartner (2001:256) translate it as "pregnancy", but also note that it is related to the Biblical Aramaic word for lust. For Halladay's (1988:84) translation of "sensory pleasure", see below.

23 For example, Halladay (1988:280) translates עצבון as "hardship, pain, distress", Koehler and Baugartner (2001:865) as "anxious toil, hardship", and Brown, Driver and Briggs (2001:781) as "pain, toil" and in Gen 3:16 as "of travail". Gesenius (2013:999) translates it as Mühsal, Beschwernis. While Gertz (2018:142) and Fischer (2018:251) both follow the translation of Mühsal, Westermann (1974:356) translates עצבון as Schmerzenzustand or Schmerzen. There are only three instances of עצבון in the Bible, in Gen 3:16, Gen 3:17 and Gen 5:29, which also leaves the translation of this word open to debate. separate nouns". This, however, is by no means certain, see for example Tsumura (1994:400), "the expression

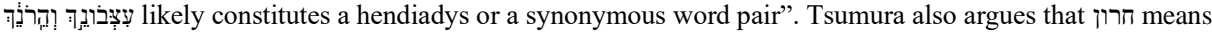
"trembling" and that together the two words mean "trembling pain". Tsumura believes that this is "related to her unique role in childbirth" (Tsumura 1994:400), but there is no reason to discount the "trembling pain" referring to painful sexual intercourse instead of childbirth. 
because God has decreed it as such, and it is woman's fault. ${ }^{25}$ By extension, if Eve's Curse is sexual pain, it is by the will of God, and it is woman's fault. The curse becomes even worse when the second part is taken into consideration - "yet your desire shall be for your husband, and he shall rule over you". In other words, a woman may experience sexual pain, and she will still want to have sexual intercourse with her husband, the very act which causes her pain, both mental and physical. This will in turn increase her mental turmoil and pain.

Female sexual pain, and the psychological anguish associated with it, as a curse from God, is incredibly problematic, and may actually, ironically, be self-fulfilling. Religious orthodoxy, or religious conservatism, and inadequate sexual education - the two often go hand-in-hand - are often considered to be culturally related predisposing factors to female sexual pain, particularly vaginismus (American Psychiatric Association 2013:439). Strict religious upbringing often exhibits negative attitudes towards sex, as well as stigmas about sex between people who are not married, and these are supported (in religious orthodoxy) by religious texts (Mizrahi 2018:46). In this regard, Bullough (1992:3) even describes traditional Western Christianity as "a sex negative religion, regarding sex as necessary for procreation, but emphasizing celibacy as the ideal". ${ }^{26}$ As stated above, according to the DSM-V, $15 \%$ of women in the USA suffer from a sexual pain disorder (American Psychiatric Association 2013:438). This aligns with a 2018 study by Mizrahi, where she references studies which cited the number of women in Western societies such as England and the USA who seek sex therapy due to some form of vaginismus as between 12\% and 17\% (Mizrahi 2018:1). This number is much higher in more religiously strict cultures. For example, Tuğrul and Kabakçi (1997:23) found that in Turkey, a conservative Islamic country, $73 \%$ of women who presented at two university clinics and a state hospital were suffering from vaginismus. Muslim, Hindu and Jewish women also appear more likely to suffer from the condition (Nasserzadeh 2015:102). The problem therefore is not with Christianity, but with religion, and specifically with what religion teaches women about sex and their (female) sexuality. It must be noted though, as Simpson and Ramberg (1992:156) observe, that the fault lies in the "severely antisexual attitude forced on the child rather than with the religious beliefs per se".

Religious orthodoxy or a strict religious upbringing is not only a cause of female sexual pain, but also a reason why it can be difficult to treat. Firstly, as noted by Simpson and Ramberg (1992:155), there is a "striking link between a highly religious upbringing and sexual dysfunctioning" which results in resistance to sex therapy, with sex therapy, or at least sex-positive therapy, being the major treatment for female sexual pain and its related psychological trauma. ${ }^{27}$ Secondly, when virginity is held as near-sacred, and sex between people who aren't married is considered sinful, then when a woman is married, she may still carry these beliefs internally, and, as Cotter (2015) states, for these women

25 See already in 1 Tim 2:11-14, "Let a woman learn in silence with full submission... For Adam was formed first, then Eve; and Adam was not deceived, but the woman was deceived and became a transgressor." For more on how the Adam and Eve story has shaped gender attitudes in Western tradition, see for example Norris (1999) and Phillips (1984).

26 For the Greco-Roman origin and influence on this emphasis on celibacy and on the notion that sex should only occur when procreation is the desired outcome, see for example Smith (1993).

27 Particularly sex therapy which makes use of cognitive-behavioural therapy (CBT). See for example Bergeron, Landry and Leclerc (2009) and Mizrahi (2018:110-111). 
it may be "difficult to flip the switch after they marry and let their body open up". Thirdly, many women have been taught by religion that it is sinful to allow any form of penetration. ${ }^{28}$ This is problematic for women suffering from vaginismus, because the primary way to deal with the physical aspects of vaginismus is through pelvic floor physical therapy and the use of vaginal dilators of increasing size made of silicone, plastic or glass inserted into the vagina to increase the size of the vaginal opening and to desensitise the area. ${ }^{29}$ Pelvic floor physical therapy for vaginismus entails a pelvic floor physical therapist inserting either dilators or their fingers into the vagina for biofeedback and exercises which encourage the strengthening and relaxing of the pelvic floor and vaginal muscles. If a woman will not allow these forms of treatment because of her religious beliefs, her options are incredibly limited, if not non-existent. Other forms of treatment (for all forms of female sexual pain) include the use of cannabidiol (CBD, a compound derived from cannabis), botulinum toxin (botox) injections in the vulva and vagina, or vestibulectomy (the surgical removal of part of the vulva), ${ }^{30}$ which seem even less likely to be acceptable options for these women.

\section{Conclusion}

Female sexual pain is a prevalent and multi-layered condition which causes physical and psychological pain and distress to those who suffer from it, but it is little known and often little understood. The inclusion of sexual pain in Ramesseum Medical Papyrus IV reveals that it was a known gynaecological condition by at least the $2^{\text {nd }}$ millennium BCE, and it was dealt with in religious or mythical narratives such as Enki and Ninhursaga and the so-called Curse of Eve in Gen 3:16. The way these texts and the religions they represent have dealt with female sexuality and female sexual pain is highly problematic. The Mesopotamian narrative explains female sexual pain as something which happens to "respectable" women, while the Genesis narrative places the cause or fault of female sexual pain squarely on the shoulders of women themselves. Women dealing with genito-pelvic pain/penetration disorder already experience feelings of shame and guilt, and these feelings may be heightened in females with religiously strict upbringings. Religious orthodoxy may both cause female sexual pain, and may stand in the way of effective treatment of women who experience it. This needs to change. The way religions treats female sexuality needs to change.

28 See for example Bullough's (1992:3) explanation that in Christian theology sexual intercourse "was permissible only if procreation was the intent, the correct orifice and instrument were used (vagina and penis), and intercourse was in the proper position (with the male on top and the female on the bottom)".

29 For more on the use of pelvic floor physical therapy and vaginal dilators in the treatment of female sexual pain, see for example Stein and Hartmann (2009), Bergeron, Landry and Leclerc (2009), Rosenbaum (2007:9) and Mizrahi (2018:110-111).

30 For the use of cannabinoids in the treatment of female sexual pain, see Gordon (2009). For the use of botox in the treatment of female sexual pain, see Pakic (2009) and Kennedy, Leclair and Boardman (2009:159-160). For the surgical treatment of female sexual pain, see Goetsch (2007) and Bornstein and Zarfati (2009). For other forms of treatment, see also Mizrahi (2018:110-111). 


\section{BIBLIOGRAPHY}

Alster, B. 1997. Proverbs of ancient Sumer: The world's earliest proverb collections. Vol. 1. Bethesda: CDL Press.

Amalraj, P., Kelly, S. and Bachmann, G.A. 2009. Historical perspective of vulvodynia. In Goldstein, A.T., Pukall, C.F. and Goldstein, I., Female sexual pain disorders: Evaluation and management. Hoboken: Wiley-Blackwell, 1-3.

American Psychiatric Association. 2000. Diagnostic and statistical manual of mental disorders. $4^{\text {th }}$ ed., text rev. Washington, DC: American Psychiatric Association.

American Psychiatric Association. 2013. Diagnostic and statistical manual of mental disorders. $5^{\text {th }}$ ed. Washington, DC: American Psychiatric Publishing.

Attinger, P. 1984. Enki et Ninhursaĝa, ZA 74:1-52.

Attinger, P. 2019. «A toujours fuir, on fuit son avenir» Remarques à propos de quelques proverbs sumériens, AoF 46/2:161-173.

Bandstra, B. 2008. Genesis 1-11: A handbook on the Hebrew text. Waco: Baylor University Press.

Barns, J.W.B. 1956. Five Ramesseum Papyri. Oxford: Oxford University Press.

Bergeron, S., Landry, T. and Leclerc, B. 2009. Cognitive-behavioral, physical therapy and alternative treatments for dyspareunia. In Goldstein, A.T., Pukall, C.F. and Goldstein, I., Female sexual pain disorders: Evaluation and management. Hoboken: Wiley-Blackwell, 150-155.

Bergeron, S., Corsini-Munt, S., Aerts, L., Rancourt, K. and Rosen, N.O. 2015. Female sexual pain disorders: a review of the literature on etiology and treatment, Current Sexual Health Reports 7/3:159-169.

Binik, Y.M., Meana, M., Berkley, K. and Shalife, S. 1999. The sexual pain disorders: Is the pain sexual or is the sex painful?, Annual Review of Sex Research 10/1:210236.

Bornstein, J. and Zarfati, D. 2009. Surgical therapy: An effective treatment for dyspareunia caused by vestibulodynia. In Goldstein, A.T., Pukall, C.F. and Goldstein, I., Female sexual pain disorders: Evaluation and management. Hoboken: Wiley-Blackwell, 162-168.

Brown, F., Driver, S. and Briggs, C. 2001. The Brown-Driver-Briggs Hebrew and English lexicon. Peabody: Hendrickson Publishers.

Bullough, V.L. 1992. Christianity and sexuality. In Green, R.M. (ed.), Religion and sexual health: Ethical, theological, and clinical perspectives. Theology and medicine 1. Dordrecht: Springer Science+Business Media, 3-16.

Costa Talens, P. and Colorado Vicente, M.J. 1971. Un problema ginecologico en el Papiro Ramesseum IV, Gaceta Médica Española 66:274-276.

Cotter, F. 2015. When tight becomes too tight: A helpful primer on vaginismus, Jezebel. Online: https://jezebel.com/when-tight-becomes-too-tight-a-helpfulprimer-on-vagin-1679485378 (Accessed: 31 October 2019).

Dicksen, K. 2007. Enki and Ninhursag: The trickster in Paradise, JNES 66/1:1-32.

Droz, J. and Howard, F.M. 2009. Endometriosis. In Goldstein, A.T., Pukall, C.F. and Goldstein, I., Female sexual pain disorders: Evaluation and management. Hoboken: Wiley-Blackwell, 124-130. 
Edzard, D.O. 2003. Sumerian grammar. Handbuch der Orientalistik 71. Atlanta: Society of Biblical Literature.

Engman, M. 2007. Partial vaginismus - Definition, symptoms and treatment.

Linköping University Medical Dissertation No. 1015. PhD dissertation, Linköping University.

Erman, A. and Grapow, H. 1982. Wörterbuch der Aegyptischen sprache. Fünfter Band. Berlin: Akademie Verlag.

Faulkner, R.O. 1991. A concise dictionary of Middle Egyptian. Oxford: Ashmolean Museum / Griffith Institute.

Fischer, G. 2018. Genesis 1-11. Herders Theologischer Kommentar zum Alten Testament. Freiburg / Basel / Wien: Herder.

Frymer-Kensky, T. 1992. In the wake of the goddesses: Women, culture and the Biblical transformation of pagan myth. New York: The Free Press.

Gardiner, A. 2001. Egyptian grammar: Being an introduction to the study of hieroglyphs. $3^{\text {rd }}$ ed., rev. Oxford: Ashmolean Museum / Griffith Institute.

Gellman, J. 2006. Gender and sexuality in the Garden of Eden, Theology \& Sexuality 12/3:319-336.

Gertz, J.C. 2018. Das erste Buch Mose (Genesis): Die Urgeschichte Gen 1-11. Das Alte Testament Deutsch 1. Göttingen: Vandenhoeck \& Ruprecht.

Gesenius, W. 2013. Hebräisches und Aramäisches Handwörterbuch über das Alte Testament. $18^{\text {th }}$ ed. Heidelberg: Springer.

Goetsch, M.F. 2007. Surgery combined with muscle therapy for dyspareunia from vulvar vestibulitis, The Journal of Reproductive Medicine 52/7:597-603.

Gordon, A.S. 2009. Vulvar pain: The neurologist's view. In Goldstein, A.T., Pukall, C.F. and Goldstein, I., Female sexual pain disorders: Evaluation and management. Hoboken: Wiley-Blackwell, 169-175.

Green, M.H. 2001. The Trotula: A Medieval compendium of women's medicine. Philadelphia: University of Pennsylvania.

Halladay, W.L. 1988. A concise Hebrew and Aramaic lexicon of the Old Testament. Leiden: Brill.

Hayes, R.D., Bennett, C.M., Dennerstein, L., Taffe, J.R. and Fairley, C.K. 2008. Are aspects of study design associated with the reported prevalence of female sexual difficulties?, Fertility and Sterility 90/3:497-505.

Jacobsen, T. 1987. The harps that once... Sumerian poetry in translation. New Haven and London: Yale University Press.

Kennedy, C.M., Leclair, C.M. and Boardman, L.A. 2009. Topical and injectable therapies for vulvar pain. In Goldstein, A.T., Pukall, C.F. and Goldstein, I., Female sexual pain disorders: Evaluation and management. Hoboken: WileyBlackwell, 156-161.

Koehler, L. and Baumgartner, W. 2001. The Hebrew and Aramaic lexicon of the Old Testament. Study ed. Vol. 1. Leiden / Boston / Köln: Brill.

Kramer, S.N. and Maier, J. 1989. Myths of Enki, the crafty god. New York, Oxford: Oxford University Press.

Krecher, J. 1966. Sumerische Kultlyrik. Wiesbaden: Otto Harrassowitz.

Leick, G. 1994. Sex and eroticism in Mesopotamian literature. London and New York: Routledge. 
LoFrisco, B.M. 2011. Female sexual pain disorders and cognitive behavioral therapy, The Journal of Sex Research 48/6:573-579.

Meyers, C. 1988. Discovering Eve: Ancient Israelite women in context. New York and Oxford: Oxford University Press.

Mizrahi, M. 2018. Culture, religion and vaginismus. PhD dissertation, California School of Professional Psychology, Alliant International University, Los Angeles.

Moss, C.R. and Baden, J.S. 2015. Reconceiving infertility: Biblical perspectives on procreation and childlessness. New Jersey: Princeton University Press.

Nasserzadeh, S. 2015. Ethnic and cultural aspects of sexuality. In Wiley, K. (ed.), $A B C$ of sexual health. $3^{\text {rd }}$ ed. Hoboken: Wiley-Blackwell, 101-103.

Norris, P. 1999. Eve: A biography. New York: New York University Press.

Nunn, J.F. 2002. Ancient Egyptian medicine. Norman: University of Oklahoma Press.

Pakic, P. 2009. Botox treatment for vaginismus, Plastic and Reconstructive Surgery $124 / 6: 455 \mathrm{e}-456 \mathrm{e}$.

Peterson, J. 2019. The literary Sumerian of Old Babylonian Ur: UET 6/1-3 in transliteration and translation with select commentary. Cuneiform Digital Library Preprints, 15-17. Available online at the CDLI.

Phillips, J.A. 1984. Eve: The history of an idea. New York: Harper and Row.

Rodin, T. 2014. The world of the Sumerian mother goddess: An interpretation of her myths. Acta Universitatis Upsaliensis: Historia Religionum 35. Uppsala: Uppsala University Press.

Römer, W.H.Ph. 1993. Mythen und Epen in sumerischer Sprache. In Janowski, B. and Schwemer, D. (eds.), Mythen und Epen I. Texte aus der Umwelt des Alten Testaments III. Gütersloh: Gütersloher Verlagshaus Gerd Mohn.

Rosenbaum, T.Y. 2007. Pelvic floor involvement in male and female sexual dysfunction and the role of pelvic floor rehabilitation in treatment: A literature review, The Journal of Sexual Medicine 4/1:4-13.

Van Ruiten, J. 2003. Eve's pain in childbearing?: Interpretations of Gen 3:16A in Biblical and early Jewish texts. In Luttikhuizen, G.P. (ed.), Eve's children: The Biblical stories retold and interpreted in Jewish and Christian traditions. Leiden and Boston: Brill, 3-26.

Shallcorss, R., Dickson, J.M., Nunns, D., Mackenzie, C. and Kiemle, G. 2018. Women's subjective experiences of living with vulvodynia: A systematic review and meta-ethnography, Archives of Sexual Behaviour 47/3:577-595.

Simpson, W.S. and Ramberg, J.A. 1992. The influence of religion on sexuality: Implications for sex therapy. In Green, R.M. (ed.), Religion and sexual health: Ethical, theological, and clinical perspectives. Theology and Medicine 1. Dordrecht: Springer Science+Business Media, 155-165.

Smith, J.E. 2018. Genesis, A commentary. Lulu.com. (Self-published online)

Smith, K.A. 1993. Inventing marital chastity: The iconography of Susanna and the elders in early Christian art, Oxford Art Journal 16/1:3-24.

Smith, K.B., Pukall, C.F. and Boyer, P.S. 2009. Psychological and relational aspects of dyspareunia. In Goldstein, A.T., Pukall, C.F. and Goldstein, I., Female sexual pain disorders: Evaluation and management. Hoboken: Wiley-Blackwell, 208212. 
Stein, A. and Hartmann, D. 2009. Physical therapy treatment of pelvic floor dysfunction. In Goldstein, A.T., Pukall, C.F. and Goldstein, I., Female sexual pain disorders: Evaluation and management. Hoboken: Wiley-Blackwell, 82-87.

Swanson, J. 1997. Dictionary of Biblical languages with semantic domains: Hebrew (Old Testament). Elec. ed. Oak Harbor: Logos Research Systems.

Tsumura, D.T. 1994. A note on חרון (Gen 3,16), Biblica 75/3:398-400.

Tuğrul, C. and Kabakçi, E. 1997. Vaginismus and its correlates, Sexual and Marital Therapy 12/1:2-34.

Ward, E. and Ogden, J. 1994. Experiencing vaginismus - Sufferers' beliefs about causes and effects, Sexual and Relationship Therapy 9/1:33-45.

Westendorf, W. 1999. Handbuch der Altägyptischen Medizin. Band I. HdO, Abt. 1.36. Leiden, Boston and Köln: Brill.

Westermann, C. 1974. Genesis 1-11. Biblischer Kommentar Altes Testament. Band I/1. Neukirchen-Vluyn: Neukirchener Verlag.

Zolnoun, D. and Shaw, C. 2009. Lieomymoas and adnexal masses: Are they a significant cause of dyspareunia? In Goldstein, A.T., Pukall, C.F. and Goldstein, I., Female sexual pain disorders: Evaluation and management. Hoboken: WileyBlackwell. 195-198. 